JURNAL KETAHANAN NASIONAL

Vol. 24, No. 3, Desember 2018, Hal 342-353

DOI:http://dx.doi.org/ 10.22146/jkn.35490

ISSN:0853-9340(Print), ISSN:2527-9688(Online)

Online sejak 28 Desember 2015 di :http://jurnal.ugm.ac.id/JKN

VOLUME 24

No. 3, Desember 2018

Halaman 342-353

\title{
Konstruksi Isu Aktual Bidang Ketahanan Nasional Untuk Pengembangan Isi Pendidikan Kewarganegaraan Persekolahan
}

\author{
Sri Haryati \\ Universitas Sebelas Maret Surakarta, Indonesia \\ Email: sriharyati52@staff.uns.ac.id \\ Wijianto \\ Universitas Sebelas Maret Surakarta, Indonesia \\ Email:wijianto@staff.uns.ac.id
}

\begin{abstract}
This study aimed to constructed the actual issues of national resilience in the development of educational content of civic education as a description of knowledge about the actual issue of citizenship in the national resilience studies as the content of civic education in school.

The research used qualitative descriptive approach. Source of informant data with purposive sampling technique, relevant document and literature study. Data collection was done through in-depth interviews, FGD, observation, and document study. The validity of data was done by triangulation process of source and method. Data analysis was done by reduction, data presentation, and conclusion.

The results showed that the description of the content of civic education was based on the actual issues of national resilience concerning ideological, political, economic, socio-cultural and security issues in the form of basic competence study which translated into indicators to achieved the objectives of basic competence. Based on data analysis, it was necessary to studied the actual issue of national resilience to supported the content of civic education education in school.
\end{abstract}

Keyword: Actual Issues, National Resilence, Civic Education.

\begin{abstract}
ABSTRAK
Penelitian ini bertujuan untuk mengkonstruksi isu aktual bidang ketahanan nasional dalam pengembangan isi pendidikan kewarganegaraan persekolahan berupa deskripsi pengetahuan tentang isu aktual kewarganegaraan bidang ketahanan nasional sebagai isi pendidikan kewarganegaraan persekolahan.

Penelitian menggunakan pendekatan deskriptif kualitatif. Sumber data informan dengan teknik purposive sampling, dokumen dan kepustakaan yang relevan. Data dikumpulkan dan diolah dengan cara wawancara mendalam, FGD, observasi, dan studi dokumen. Validitas data dilakukan melalui proses trianggulasi sumber dan metode. Data dianalisis melalui reduksi data, pemyajian data, dan penarikan kesimpulan.

Penelitian ini menemukan rumusan tentang deskripsi isi pendidikan kewarganegaraan berdasarkan isu aktual bidang ketahanan nasional yaitu tentang isu-isu ipoleksosbudhankam berupa kajian kompetensi dasar yang diterjemahkan menjadi indikator-indikator untuk mencapai tujuan dari kompetensi dasar tersebut. Berdasarkan analisis data, diperlukan kajian isu aktual ketahanan nasional untuk mendukung isi pendidikan kewarganegaraan persekolahan.
\end{abstract}

Kata Kunci: Isu Aktual, Ketahanan Nasional, Pendidikan Kewarganegaraan 


\section{PENGANTAR}

Ilmu pengetahuan selalu berubah dan berkembang, demikian juga bidang pendidikan. Perubahan dalam bidang pendidikan membawa pengaruh terhadap perubahan pandangan mengenai kurikulum. Kurikulum yang semula hanya dipandang sebagai sejumlah mata pelajaran saja, kemudian beralih makna menjadi semua kegiatan atau semua pengalaman belajar yang diberikan kepada siswa di bawah tanggung jawab sekolah untuk mencapai tujuan pendidikan (Alberty, 1954: 12).

Pengertian kurikulum tersebut di atas menunjukkan pengertian/makna yang lebih luas sebab kurikulum tidak hanya terbatas pada mata pelajaran saja, akan tetapi semua aspek yang dapat mempengaruhi pribadi siswa, dengan kata lain kurikulum sebagai alat untuk mencapai tujuan pendidikan. Walaupun demikian, kurikulum dalam pengertian ini pun masih belum memberikan arah secara operasional, serta belum ada batasan yang jelas mengenai apa yang dimaksud dengan kata 'semua kegiatan', apa isinya dan bagaimana bentuknya. Oleh sebab itu akhirnya disepakati bahwa kurikulum dipandang/diartikan sebagai program belajar bagi siswa yang disusun secara sistematik, dan diberikan oleh lembaga pendidikan tertentu untuk mencapai tujuan pendidikan. Sebagai program, kurikulum merupakan niat atau harapan. Atas dasar itu, ada pandangan yang menyatakan bahwa kurikulum tidak lain merupakan hasil belajar yang diniati/diharapkan atau intended learning outcome (Tanner, 1975: 26).

Sudjana (2017: 3) juga memiliki pandangan tentang kurikulum seperti yang telah dijelaskan di atas, bahwa kurikulum merupakan program belajar atau dokumen yang berisikan hasil belajar yang diniati atau diharapkan dimiliki siswa di bawah tanggung jawab sekolah untuk mencapai tujuan pendidikan. Program belajar masih bersifat umum yang memerlukan penjabaran lebih lanjt oleh guru sebelum diberikan kepada siswa melalui proses pengajaran. Kurikulum sebagai program belajar bagi siswa harus memiliki tujuan program yang harus dicapai, isi program yang harus diberikan, dan strategi/ cara bagaimana melaksanakan program tersebut.

Salah satu bentuk penyesuaian terhadap perubahan kurikulum ialah pengembangan isi pembelajaran. Peneliti mencoba melakukan pengembangan isi pembelajaran Pendidikan Kewarganegaraan Persekolahan yang khas yaitu pada tingkat Sekolah Menegah Kejuruan (SMK). Pembelajaran di SMK memiliki keunikan sendiri karena pada dasarnya ciri khas dari pendidikan SMK mengarah pada suatu praktik lapangan. Dalam pembelajaran Pendidikan Kewarganegaraan hal itu dapat disiasati melalui analisis isu atau kasus-kasus yang berkembang di lapangan atau di masyarakat. Namun begitu, perlu pengembangan yang tepat dan sesuai sasaran terkait dengan proses konstruksi isi Pendidikan Kewarganegaraan Persekolahan di SMK, utamanya yaitu penyusunan indikator pembelajaran yang bersumber dari pemetaan kompetensi dasar pada setiap level pembelajaran.

Pada prinsipnya, pendidikan kewarganegaraan merupakan suatu hal yang khas dari bangsa yang bersangkutan. Oleh karena itu pendekatannya lebih inward looking melalui pendekatan kesejarahan. Meskipun kita bisa melakukan pengembangannya melalui outward looking, misal melalui pendekatan perbandingan dengan civic education dari berbagai negara, namun kesemuanya 
dikembalikan dan dikontekstualisasikan pada kepentingan bangsa yang bersangkutan.

Adapun fenomena yang berkembang dalam dunia pendidikan yaitu Kurikulum 2013 yang sedang menjadi tren yang luar biasa di dunia pendidikan Indonesia, bagaimana bisa tidak, karena pada dasarnya kurikulum merupakan acuan dalam pelaksanaan pendididikan di negeri ini. Adanya perubahan kurikulum telah berdampak secara sistemik dalam proses kegiatan belajar mengajar, maksudnya akan berdampak pada keberlangsungan kegiatan belajar megajar, baik pada penyusunan rencana atau pembuatan RPP, termasuk pemetaan indikator maupun pada ranah praktiknya nanti.

Fenomena perkembangan Kurikulum 2013 yang seharusnya menjadi solusi berbagai macam permasalahan pendidikan, kenyataanya belum dapat menyelesaikan berbagai macam permasalahan pendidikan yang terjadi selama ini. Kegiatan proses belajar mengajar yang seharusnya sudah student centered learning, masih terkendala proses pembelajaran yang belum sepenuhnya dikuasai oleh guru dalam konsep student centered learning dimana guru seharusnya menjadi fasilitator, bukan sebagai person yang mendominasi di kelas. Pada PKn persekolahan, permasalahan yang muncul salah satunya adalah masalah konstruksi isi materi pembelajaran tertentu yang perlu dikaji ulang agar sesuai dengan tujuan dari pendidikan kewarganegaraan pada umumnya. Dalam penelitian ini, peneliti melakukan proses konstruksi isu aktual dalam bidang ketahanan nasional yang digunakan sebagai pengembangan isi materi pendidikan kewarganegaraan persekolahan di jenjang Sekolah Menengah Kejuruan (SMK).

Terkait dengan pentingnya kajian kurikulum dalam proses pendidikan, Kuntarti
(2014) menegaskan bahwa perubahan kurikulum berimplikasi pada pencapaian kualitas sumber daya manusia. Perubahan pada kurikulum akan berdampak pada perubahan sistem dan proses pembelajaran, yang kemudian akan bersinggungan dengan kegiatan belajar mengajar di kelas. Hal ini menegaskan bahwa kajian tentang isi kurikulum merupakan hal yang penting dan mendasar dalam sistem pendidikan dan pembelajaran. Selajutnya, Suwignyo dan Yuliantri (2018) memaparkan bahwa praktik belajar kewargaan dalam kehidupan seharihari merupakan suatu bentuk ketahanan sosial masyarakat yang dapat terus dikembangan dalam kehidupan sosial masyarakat Indonesia. Adapun praktik kewarganegaraan merupakan salah satu proses pembelajaran yang dipelajari dan diimplementasikan dalam pembelajaran PPKn yang dikenal dengan project citizen.

Adapun landasan konseptual yang digunakan peneliti di antaranya ialah teori ketahanan nasional dan pembelajaran pendidikan kewarganegaraan. Studi yang menganalisis ketahanan dalam istilah nasional sangat sedikit dan jauh. Konsep ketahanan nasional telah muncul dalam literatur pada pengakuan bahwa kekuatan suatu negara tidak dapat dievaluasi semata-mata oleh kapasitas militer, tetapi juga oleh aspek politik-psikologis (Barnett, 2004: 64-66). Seperti pada tingkat individu yang dijelaskan di atas, ketahanan di tingkat nasional juga berhubungan dengan proses menyesuaikan diri dan menyerap kesulitan atau perubahan yang didikte oleh ancaman eksternal (Shaul \& Yohanan, 2009: 70-89).

Pada dasarnya, ketahanan nasional erat kaitannya dengan kepribadian bangsa. Kepribadian bangsa harus menjadi modal dasar dari ketahanan pribadi oleh setiap 
individu, sehingga kepribadian bangsa dapat dikembangkan untuk mewujudkan ketahanan nasional. Setiap individu diharapkan mampu memiliki pribadi yang tercermin di dalam Pancasila, sehingga mampu mewujudkan cita-cita bangsa Indonesia. Soedarsono (1997: 51) menjelaskan ciri-ciri utama yang harus ada dalam diri manusia Indonesia yang berkepribadian Pancasila, yaitu religius dan cinta tanah air, mendambakan kerukunan dan kebersamaan, serta meyakini adanya kesamaan hak dan tidak adanya dominasi dari satu terhadap yang lain.

Apabila mengambil makna dari pengertian ketahanan nasional tersebut, yang menjelaskan adanya keuletan dan ketangguhan yang mengandung kemampuan dan sebagainya, maka pada hakikatnya diperlukan penempatan dan ketangguhan yang akan menghasilkan suatu kekuatan ke dalam dan kekuatan ke luar, harus mencerminkan ketahanan pribadi yang paling dasar. Kepribadian seseorang harus dapat ditempa keuletan dan ketangguhan untuk memiliki suatu ketahanan yang secara tertutup menjadi tangguh (Soedarsono, 1997: 52-53). Adapun apabila dijabarkan, secara prinsip teori ketahanan nasional membahas tentang delapan pokok bahasan penting, berupa Asta Gatra atau delapan gatra yang menjadi pokok bahasan ketahanan nasional. Dari Asta Gatra ini, kemudian dapat dilakukan analisis isu-isu aktual yang terkait dengan pendidikan kewarganegaraan persekolahan.

Friedland (2006: 7-10) menjelaskan bahwa di tingkat nasional, ketahanan adalah kemampuan masyarakat untuk bertahan menghadapi kesulitan dan krisis di berbagai bidang dengan menerapkan perubahan dan adaptasi tanpa merusak nilai-nilai inti dan institusi atau karakteristik masyarakat. Namun, tingkat ketahanan nasional dapat dilihat dalam dua cara yang berbeda, di satu sisi ketahanan nasional mengungkapkan kemampuan masyarakat untuk menahan kesulitan dengan nilai-nilai kultur masyarakat. Di sisi lain, ketahanan seperti itu mungkin akan tercermin dalam menyesuaikan kembali dan beradaptasi dengan cara baru dan inovatif, seperti adaptasi perilaku yang membantu menutup kesenjangan antara ketegangan saat ini dan kebutuhan dan kemampuan masyarakat (Elran, 2006; Kirschenbaum, 2006). Selanjutnya, di tingkat nasional, di luar pola perilaku baru yang muncul sebagai reaksi terhadap ancaman, sikap dan persepsi politik dan sosial juga telah ditemukan untuk menentukan kemampuan suatu bangsa untuk tahan situasi krisis dan konflik yang sedang berlangsung (Bermanis, 2007). Dimensi yang dapat diukur seperti itu adalah patriotisme, optimisme, sosial integrasi, dan kepercayaan politik. Keempat dimensi ini merupakan pengukuran praktis ketahanan nasional yang ditarik dari perspektif modal sosial. Kapasitas masyarakat untuk beradaptasi dengan kemalangan dibatasi dalam penerimaan sosial pilihan untuk adaptasi (Adger, 2003: 388). Jadi, kebulatan suara atau setidaknya luas kesepakatan mengenai kebijakan nasional menuju keamanan penting dalam mengevaluasi kapasitas penduduk untuk menyerap kesulitan tak terduga atau yang sedang berlangsung. Dengan kata lain, kami menyarankan bahwa ketahanan nasional harus diukur sesuai dengan sikap politikpsikologis seperti kekuatan demokrasi dan kepercayaan dalam kepemimpinan daripada hanya mengandalkan pada dimensi perilaku dan mental individu dalam masyarakat. 
Terkait dengan pembelajaran pendidikan kewarganegaraan persekolahan dijelaskan oleh Wuryan \& Syaifullah (2008: 53-54) bahwa pendekatan dalam pembelajaran pendidikan kewarganegaraan persekolahan haruslah menekankan keterlibatan peserta didik dalam setiap kegiatan belajar mengajar dengan adanya partisipasi aktif dalam menemukan ide positif untuk melatih memecahkan masalah. Oleh sebab itu, sangat penting diperlukan suatu isi materi yang sesuai dan harus disusun melalui standar proses penyusunan isi materi pembelajaran.

Penelitian menggunakan pendekatan deskriptif kualitatif. Sumber data informan dengan teknik purposive sampling, dokumen dan kepustakaan yang relevan. Data dikumpulkan dengan cara wawancara mendalam, Focus Group Discussion (FGD), observasi, dan studi dokumen. Analisis data menggunakan analisis interaktif yang mencakup reduksi data, sajian data, verifikasi data dan penarikan kesimpulan dan dilakukan secara terus menerus dari sejak pengumpulan data hingga verifikasi sejak awal sampai saat selesai serta selalu menguji antar komponen secara terus menerus sehingga kesimpulan yang di dapat bisa teruji dengan selektif dan akurat (gambar 1).

\section{PEMBAHASAN}

\section{Konstruksi Isu Aktual Bidang Ketahanan Nasional}

Konstruksi isu aktual bidang ketahanan nasional dilakukan dengan analisis isu-isu terkait dengan Asta Gatra bidang ketahanan nasional yaitu ideologi, politik, ekonomi, sosial budaya, dan hankam. Berdasarkan data yang didapat melalui Focus Group Discussion dengan Guru PPKn SMK Kota Solo, diperoleh analisis isu aktual bidang ketahanan nasional yang dibagi menjadi lima isu yaitu isu ideologi, isu politik, isu ekonomi, isu sosial budaya, dan isu pertahanan keamanan.

Pertama, isu ideologi. Isu ideologi dilihat dari berbagai macam ancaman ideologi negara. Peserta FGD mengidentifikasi beberapa ancaman yang dikategorikan sebagai ancaman potensial dan ancaman faktual. Ancaman faktual terhadap ideologi adalah bahaya yang mengancam suatu negara namun tujuan dari ancaman tersebut maksudnya tidak jelas. Ancaman tersebut adalah (1). Ancaman globalisasi. Melalui globalisasi ini nilai-nilai yang berasal dari negara lain ikut masuk ke terhadap negara, dan dapat mempengaruhi pandangan dan

Gambar 1

Model Analisis Interaktif HB

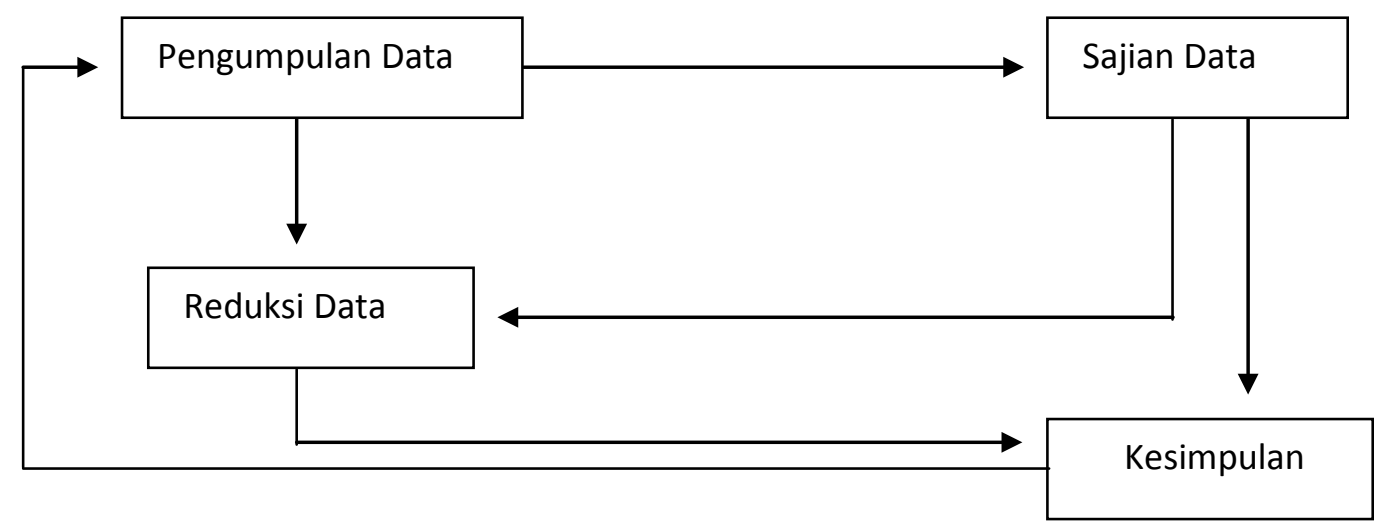

(Sumber: Miles \& Huberman, 1992) 
pemikiran masyarakat terhadap ideologi negara. Ancaman potensial di bidang ideologi berkenaan dengan pola pikir dalam berbangsa dan bernegara yang cenderung dapat dipengaruhi oleh pemikiran dan pandangan dari negara lain yang tak jarang bertentangan dengan norma masyarakat. Pengaruh globalisasi terhadap perubahan nilai-nilai dalam masyarakat harus diwaspadai. (2). Ancaman kelompok radikal. Radikalisme dan gerakan terorisme merupakan ancaman faktual. Berbeda dengan ancaman potensial yakni ancaman yang muncul akibat dendam lama yang kembali mengemuka sehingga menimbulkan bahaya yang serius. Contoh nyata adanya ISIS yang menyebarkan ideologinya dan tidak menutup kemungkinan dapat menggoyahkan ideologi Pancasila.

Kedua, isu politik. Isu politik merupakan isu-isu terkait kebijakan politik. Isu politik tertuju pada mereka yang berwenang membuat kebijakan, misalnya upaya yang bersifat konsepsional dengan mengubah pola pikir seakan-akan keputusan yang diusulkannya adalah yang terbaik. Peserta FGD mengidentifikasi terkait dengan partisipasi politik pada siswa SMK. Pada dasarnya siswa tingkat SMK dalam dunia politik termasuk dalam pemilih pemula. Pengetahuan politik bagi pemilih pemula harus terus ditingkatkan melalui pendidikan politik dan isu-isu yang terkait dengan politik. Hal ini untuk menghindari adanya kalangan yang memanfaatkan pemilih pemula untuk kepentingan politiknya. Sebagai siswa, pemilih pemula harus cerdas dalam menanggapi isu politik dan mampu memilih pilihan politiknya sesuai dengan informasi yang diperoleh dari berbagai macam sumber.
Terkait dengan isu politik ini, Saputro (2015) menjelaskan bahwa pendidikan politik merupakan pendidikan yang sangat penting bagi generasi muda, karena pada akhirnya, proses politik dapat mempengaruhi aspekaspek kehidupan yang lain. Selain partai politik, pendidikan politik juga dilakukan di sekolah, terutama melalui mata pelajaran PPKn.

Ketiga, isu ekonomi. Isu ekonomi dapat dilihat tantangan kelangsungan ekonomi bangsa. Dalam ranah siswa SMK, menurut peserta FGD, isu tentang ekonomi berkaitan dengan kewirausahaan. Bahwa tren dunia usaha saat ini, seharusnya menjadi peluang bagi para pemuda untuk menunjukkan dirinya sebagai pengusaha muda.

Adanya perkembangan teknologi dan berkembangnya start up \& e-commerce menjadi peluang tersendiri bagi siswasiswi SMK untuk berkreasi dalam dunia kewirausahaan digital. Namun di sisi lain, ada ancaman yang serius terkait start up $\&$ e-commerce ini, yaitu apabila generasi muda tidak memahami dan tidak memiliki kemampuan untuk turut bersaing dalam dunia wirausaha digital, maka bisa jadi bangsa Indonesia hanya akan menjadi konsumen dari perkembangan ekonomi modern.

Keempat, isu sosial-budaya. Isu sosial budaya dapat dilihat dari adat dan kebiasaan masyarakat. Peserta FGD mengidentifikasi dua jenis ancaman potensial terkait isu sosial budaya. Terpaan isu-isu terkait suku, agama, ras, dan antar golongan (SARA) yang dapat mengarahkan konflik yang memecah belah antar sesama. Ancaman faktual yang berasal dari luar \& aktor non negara adalah terkait dengan sistem kepercayaan, misalnya masuknya ajaran radikalisme dan politisasi agama. Ancaman selanjutnya yang bersifat 
potensial adalah miskinnya kesadaran tentang arti Bhineka Tunggal Ika.

Kelima, isu pertahanan-keamanan. Isu pertahanan-kemanan dapat dilihat dari berbagai dimensi dari keamanan nasional. Peserta FGD mengidentifikasi tiga jenis ancaman di bidang pertahanan-keamanan, yaitu (1). Ancaman terhadap perbatasan wilayah negara. Perbatasan wilayah negara ini merupakan ancaman yang sangat berpengaruh terhadap keamanan dan pertahanan negara, seperti konflik perbatasan dengan Negara Malaysia terkait kepemilikan pulau Pulau Sipadan dan Ligitan yang kemudaian dimenangkan Malaysia. Kasus seperti ini sangat berpotensi terjadi di kemudian hari. Contoh, peristiwa yang belum lama terjadi adalah kasus Laut Natuna di dekat Laut Cina Selatan. Pelanggaran dilakukan oleh kapal perang negara Tiongkok ini mengaku bahwa perbatasan tersebut tidak dilanggar oleh mereka, namun pada kenyataannya itu memang terjadi. (2). Ancaman perang asimetris/perang proxy. Metode yang digunakan distraktif dan manipulatif dan biasanya melibatkan lembaga penyandang dana, black operation, aktivitas intelejen. Penyerangan tersebut untuk menyerang stabilitas negara. Perang asimetris dilakukan secara diam-diam dilakukan seperti obat nyamuk yakni menyerang dari ujung dahulu. (3). Ancaman dunia digital. Tersebarnya berbagai macam berita hoax yang isinya menebarkan kebencian, juga merupakan salah satu ancaman yang serius bagi generasi muda. Generasi muda harus cerdas dan tidak mudah menerima informasi tanpa adanya kroscek informasi yang lain. Hal ini untuk menghindari penyebaran berita atau informasi yang tidak benar dan isinya cenderung berisi ujaran kebencian.

\section{Pengembangan Isi Pendidikan Kewarganegaraan Persekolahan}

Setelah dilakukan analisis isu-isu aktual ketahanan nasional, selanjutnya masuk ke tahap pengembangan isi pendidikan kewarganegaraan persekolahan. Konstruksi isi dilakukan melalui pemetaan Kompetensi Dasar ke dalam indikator-indikator untuk dikembangkan dalam manteri-materi. Agar penjabaran materi-materi itu relevan dengan tujuan yang diharapkan, Kosasih (2014: 3233) menjelaskan bahwa perlu diperhatikan kriteria penyeleksian dan pemilihannya seperti berikut.

Pertama, sahih. Materi yang akan dituangkan dalam pembelajaran benar-benar telah teruji kebenaran dan kesahihannya. Pengertian ini juga berkaitan dengan keaktualan materi sehingga materi yang diberikan dalam pembelajaran tidak ketinggalan zaman dan memberikan kontribusi untuk pemahaman ke depan.

Kedua, tingkat kepentingan/ kebermanfaatannya (significance). Dalam pemilihan materi perlu dipertimbangkan beberapa pertanyaan, seperti sejauh mana materi tersebut penting untuk dipelajari?; penting untuk siapa?; mengapa penting?. Manfaat suatu materi pembelajaran memang harus dilihat dari semua sisi, baik secara akademis artinya guru harus yakin bahwa materi yang diajarkan dapat memberikan dasar-dasar pengetahuan dan keterampilan yang dikembangkan lebih lanjut pada jenjang pendidikan berikutnya. Bermanfaat secara non-akademis maksudnya bahwa materi yang diajarkan dapat mengembangkan kecakapan hidup dan sikap yang dibutuhkan dalam kehidupan sehari-hari.

Ketiga, menarik minat (interest). Materi yang dipilih hendaknya menarik 


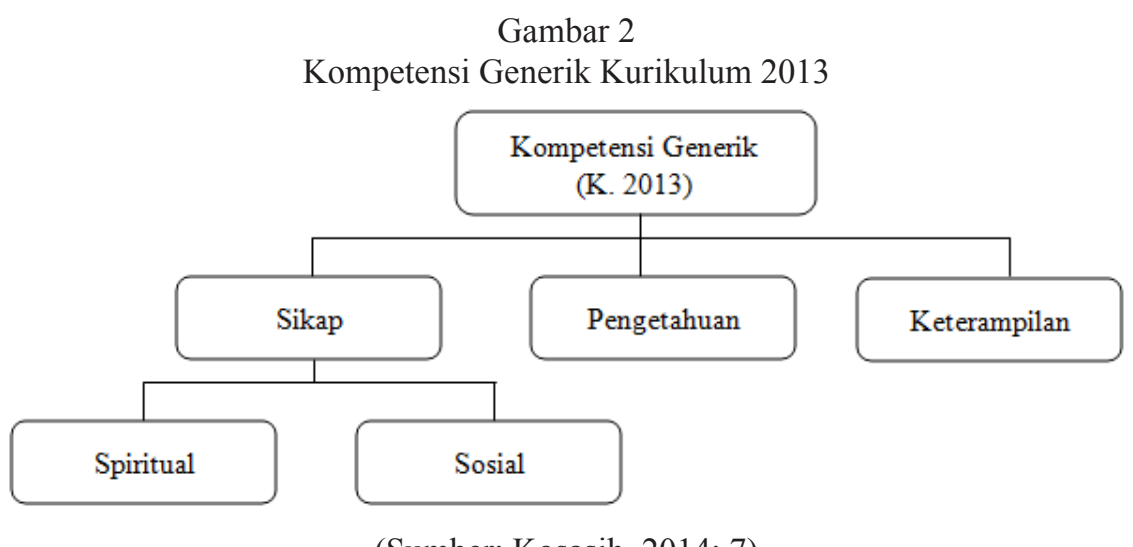

(Sumber: Kosasih, 2014: 7)

minat dan dapat memotivasi siswa untuk mempelajarinya lebih lanjut. Setiap materi yang diberikan kepada siswa harus mampu menumbuhkembangkan rasa ingin tahu sehingga memunculkan dorongan untuk mengembangkan sendiri kemampuan mereka.

Keempat, konsisten (keajegan). Hal ini terkait dengan contoh, teori, prosedur, dan prinsip yang lainnya. Sebagaimana yang dapat dimaklumi bahwa setiap mata pelajaran memungkinkan memiliki sudut pandang yang beragam. Keberagaman referensi perlu diperdalam guna menghindari munculnya pemahaman yang keliru tentang materi yang dipelajari.

Kelima, adekuasi (kecukupan). Materi yang diajarkan hendaknya cukup memadai dalam membantu siswa dalam menguasai suatu kompetensi. Materi tidak boleh terlalu sedikit dan tidak boleh terlalu banyak. Jika terlalu sedikit, materi itu kurang membantu tercapainya suatu kompetensi dasar. Sebaliknya, jika terlalu banyak akan mengakibatkan keterlambatan dalam pencapaian target kurikulum (pencapaian keseluruhan KD).

Selanjutnya, dalam kurikulum 2013, perlu diperhatikan beberapa aspek utama atau penting dalam proses pembelajaran sebagai berikut (gambar 2).
Atas dasar kelima hal di atas, peneliti kemudian melakukan analisis pemetaan indikator pada kompetensi dasar pendidikan kewarganegaraan persekolahan di SMK.

\section{Analisis Pemetaan Kompetensi Dasar (KD) PKn SMK Terkait Isu Aktual Ketahanan Nasional}

Analisis pemetaan kompetensi dasar Pendidikan Kewarganegaraan SMK yang terkait isu aktual ketahanan nasional dapat dilihat pada tabel 1 .

Selanjutnya, setelah analisis keterkaitan KD dengan isu-isu aktual ketahanan nasional, konstruksi isi materi Pendidikan Kewarganegaraan berdasarkan isu aktual bidang ketahanan nasional dilakukan dengan pengembangan Kompetensi Dasar Menjadi Indikator, seperti terlihat pada tabel 2.

Pemetaan indikator pada tabel 2, dilakukan oleh peneliti berdasarkan proses penelitian yang telah dilakukan berupa kajian tentang kompetensi dasar melalui Focus Group Discussion dengan para pakar dan guru Pendidikan Kewarganegaraan. Adanya pemetaan indikator berguna untuk menyiapkan perangkat pembelajaran dan sebagai acuan capaian pembelajaran apa yang ingin diwujudkan dalam proses pembelajaran, khususnya pembelajaran Pendidikan Kewarganegaraan. 
Tabel 1

Analisis Komptensi Dasar Terkait Dengan Isu Aktual Ketahanan Nasional

\begin{tabular}{|c|c|}
\hline \multicolumn{2}{|c|}{ Kelas X } \\
\hline Kompetensi Dasar & Analisis \\
\hline $\begin{array}{l}\text { Mengidentifikasi faktor-faktor pembentuk integrasi } \\
\text { nasional dalam bingkai Bhinneka Tunggal Ika }\end{array}$ & $\begin{array}{l}\text { Faktor-faktor pembentuk integrasi nasional dalam } \\
\text { bingkai Bhineka Tunggal Ika dapat ditelaah dengan } \\
\text { kajian isu aktual dalam bidang ideologi dan kajian } \\
\text { multikulturalisme }\end{array}$ \\
\hline
\end{tabular}

Menganalisis ancaman terhadap negara dan upaya KD ini sesuai dan dapat dikembangan konstruksi materi penyelesaiannya di bidang ideologi, politik, ekonomi, berdasarkan isu-isu aktual ketahanan nasional, terutama sosial, budaya, pertahanan, dan keamanan dalam bingkai isu Ipoleksosbudhankam

Bhineka Tunggal Ika

Menginterpretasi pentingnya Wawasan Nusantara dalam Wawasan nusantara merupakan bagian dari wawasan konteks Negara Kesatuan Republik Indonesia kebangsaan yang sangat vital dan perlu untuk dikontruksi dengan isu aktual ketahanan nasional

Mendemonstrasikan faktor-faktor pembentuk integrasi Isu aktual ketahanan nasional dapat dijadikan sebagai bahan nasional dalam bingkai Bhinneka Tunggal Ika demonstrasi faktor-faktor pembentuk integrasi nasional

Menyaji hasil analisis tentang ancaman terhadap negara Dalam proses menyaji, dilakukan diskusi mendalam dan upaya penyelesaiannya di bidang Ideologi, politik, untuk mengkonstruksi isu-isu aktual ketahanan nasional ekonomi, sosial, budaya, pertahanan, dan keamanan dalam pembelajaran PPKn

Mempresentasikan hasil interpretasi terkait pentingnya Dilakukan refleksi hasil intepretasi untuk menghasilkan Wawasan Nusantara dalam konteks Negara Kesatuan konstrulsi indikator dan materi berdasarkan isu-isu aktual Republik Indonesia

Kelas XI

Kompetensi Dasar Analisis

Mengkaji kasus-kasus ancaman terhadap Ideologi, Kajian kasus dilakukan dengan analisis isu aktual politik, ekonomi, sosial, budaya, pertahanan, dan ketahanan nasional sebagai bahan kajian untuk keamanan dan strategi mengatasinya dalam bingkai merumuskan strategi yang tepat dalam perumusan solusi Bhinneka Tunggal Ika

Mengidentifikasikan faktor pendorong dan penghambat Melakukan pemetaan analisis SWOT terkait dengan persatuan dan kesatuan bangsa dalam Negara Kesatuan fenomena persatuan kesatuan yang sesuai dengan isu-isu Republik Indonesia aktual ketahanan nasional

Merancang dan melakukan penelitian sederhana tentang Memperdalam kajian isu-isu aktual ketahanan nasional potensi ancaman terhadap Ideologi, politik, ekonomi, secara sistematis dan metodologis terkait dengan isu-isu sosial, budaya, pertahanan, dan keamanan dan strategi ipoleksosbudhankam mengatasinya dalam bingkai BhinnekaTunggal Ika

Menyaji hasil identifikasi tentang faktor pedorong dan Mendiskusikan hasil analisis SWOT yang telah dibuat penghambat persatuan dan kesatuan bangsa dalam untuk kemudian merumuskan solusi isu-isu aktual Negara Kesatuan Republik Indonesia ketahanan nasional

\begin{tabular}{|c|c|}
\hline \multicolumn{2}{|c|}{ Kelas XII } \\
\hline Kompetensi Dasar & Analisis \\
\hline $\begin{array}{l}\text { Mengidentifikasi pengaruh kemajuan ilmu pengetahuan } \\
\text { dan teknologi terhadap negara dalam bingkai Bhinneka } \\
\text { Tunggal Ika }\end{array}$ & $\begin{array}{l}\text { Melakukan kajian perkembangan } \\
\text { dan komunikasi dalam isu-isu aktu }\end{array}$ \\
\hline $\begin{array}{l}\text { Mengevaluasi dinamika persatuan dan kesatuan bangsa } \\
\text { sebagai upaya menjaga dan mempertahankan Negara } \\
\text { Kesatuan Republik Indonesia }\end{array}$ & $\begin{array}{l}\text { Evaluasi dilakukan dengan membuat analisis dampak } \\
\text { dari isu-isu aktual ketahanan nasional yang dikaji }\end{array}$ \\
\hline $\begin{array}{l}\text { Mempresentasikan hasil identifikasi pengaruh kemajuan } \\
\text { ilmu pengetahuan dan teknologi terhadap negara dalam } \\
\text { bingkai Bhinneka Tunggal Ika }\end{array}$ & $\begin{array}{l}\text { Pengaruh perkembangan kemajuan ilmu pengetahuan } \\
\text { dan teknologi dipresentasikan dan didiskusikan untuk } \\
\text { memperoleh analisis solusi permasalahan dalam isu-isu } \\
\text { aktual ketahanan nasional }\end{array}$ \\
\hline $\begin{array}{l}\text { Merancang dan mengkampanyekan persatuan } \\
\text { dan kesatuan bangsa sebagai upaya menjaga } \\
\text { dan mempertahankan Negara Kesatuan Republik } \\
\text { Indonesia }\end{array}$ & $\begin{array}{l}\text { Hasil kajian isu-isu aktual ketahanan nasional } \\
\text { disebarluaskan melalu berbagai media untuk menyebarkan } \\
\text { informasi tentang jiwa kritis warga negara terkait dengan } \\
\text { isu-isu aktual ketahanan nasional }\end{array}$ \\
\hline
\end{tabular}


Tabel 2

Pemetaan Indikator Dari Kompetensi Dasar PKn SMK Terkait Dengan Isu Aktual Ketahanan Nasional

\begin{tabular}{ccc}
\hline & Kelas X \\
\hline Kompetensi Dasar & Indikator \\
\hline
\end{tabular}

Mengidentifikasi faktor-faktor pembentuk integrasi Menjelaskan faktor-faktor pembentuk integrasi nasional. nasional dalam bingkai Bhinneka Tunggal Ika

Menganalisis faktor-faktor pembentuk integrasi nasional dalam bingkai Bhineka Tunggal Ika.

Menganalisis ancaman terhadap negara dan upaya Menganalisis isu-isu aktual ketahanan nasional dalam penyelesaiannya di bidang ideologi, politik, ekonomi, bidang ipoleksosbud-hankam.

sosial, budaya, pertahanan, dan keamanan dalam bingkai

Bhineka Tunggal Ika

Mengkaji keterkaitan isu-isu aktual ketahanan nasional dalam bingkai Bhineka Tunggal Ika.

Menginterpretasi pentingnya Wawasan Nusantara dalam Menjelaskan teori wawasan nusantara.

konteks Negara Kesatuan Republik Indonesia

Menganalisis isu aktual ketahanan nasioal berdasarkan teori wawasan nusantara dalam konteks NKRI.

Mendemonstrasikan faktor-faktor pembentuk integrasi Menjelaskan teori integrasi nasional.

nasional dalam bingkai Bhinneka Tunggal Ika

Menganalisis faktor-faktor pembentuk intergasi nasional terkait

dengan isu aktual ketahanan nasional dalam bingkai

Bhineka Tunggal Ika

Menyaji hasil analisis tentang ancaman terhadap negara Mengkaji isu aktual ketahanan nasional terkait dengan dan upaya penyelesaiannya di bidang ideologi, politik, ancaman terhadap negara.

ekonomi, sosial, budaya, pertahanan, dan keamanan

Mempresentasikan analisis isu aktual ketahanan nasional pada masing-masing isu ipoleksosbudhankam.

Mempresentasikan hasil interpretasi terkait pentingnya Mengkaji keterkaitan teori wawasan nusantara dengan Wawasan Nusantara dalam konteks Negara Kesatua n isu-isu aktual ketahanan nasional.

Republik Indonesia

Mempresentasikan hasil kajian isu aktual ketahanan nasioal berdasarkan teori wawasan nusantara dalam konteks NKRI.

\section{Kelas XI}

Kompetensi Dasar Indikator

Mengkaji kasus-kasus ancaman terhadap Ideologi, Menganalisis kasus-kasus ancaman ideologi, politik, politik, ekonomi, sosial, budaya, pertahanan, dan ekonomi, sosial, budaya, pertahanan dan kemanan. keamanan dan strategi mengatasinya dalam bingkai Bhinneka Tunggal Ika

Mengkaji isu-isu aktual ketahanan nasional yang berkaitan dengan kasus-kasus dalam bidang ipoleksosbudhankam.

Mengidentifikasikan faktor pendorong dan penghambat Menjelaskan faktor-faktor pendorong dan penghambat persatuan dan kesatuan bangsa dalam Negara Kesatuan persatuan bangsa.

Republik Indonesia

Menganalisis faktor-faktor pendorong dan penghambat persatuan bangsa dalam NKRI.

Merancang dan melakukan penelitian sederhana tentang Mengkaji potensi dan ancaman terhadap potensi ancaman terhadap Ideologi, politik, ekonomi, ipoleksosbudhankam.

sosial, budaya, pertahanan, dan keamanan dan strategi mengatasinya dalam bingkai BhinnekaTunggal Ika

Menganalisis strategi mengatasi ancaman brdasarkan pada kajian isu-isu aktual ketahanan nasional

Menyaji hasil identifikasi tentang faktor pedorong dan penghambat persatuan dan kesatuan bangsa dalam Negara Kesatuan Republik Indonesia

Menganalisis faktor pendorong dan penghambat persatuan dan kesatuan bangsa dalam kajian isu-isu aktual ketahanan nasional.

Mempresentasikan faktor pendorong dan penghambat persatuan dan kesatuan bangsa dalam kajian isu-isu aktual ketahanan nasional dalam NKRI. 


\begin{tabular}{c}
\hline Kolas XII \\
\hline Indikator \\
\hline Mengidentifikasi pengaruh kemajuan ilmu pengetahuan
\end{tabular}

Mengidentifikasi pengaruh kemajuan ilmu pengetahuan Menjelaskan pengaruh kemajuan ilmu pengetahuan dan dan teknologi terhadap negara dalam bingkai Bhinneka teknologi.

Tunggal Ika

Mengkaji pengaruh kemajuan ilmu pengetahuan dan teknologi terkait dengan isu aktual ketahanan nasional dalam bingkai Bhineka Tunggal Ika.

Mengevaluasi dinamika persatuan dan kesatuan bangsa Menganalisis dinamika persatuan dan kesatuan bangsa sebagai upaya menjaga dan mempertahankan Negara melalui isu aktual ketahanan nasional.

Kesatuan Republik Indonesia

Mengkaji dinamika persatuan dan kesatuan bangsa sebagai upaya menjaga dan mempertahankan NKRI.

Mempresentasikan hasil identifikasi pengaruh kemajuan ilmu pengetahuan dan teknologi terhadap negara dalam bingkai Bhinneka Tunggal Ika

Mengkaji keterkaitan isu aktual ketahanan nasional dengan pengaruh kemajuan ilmu pengetahuan dan teknologi.

Mempresentasikan kajian pengaruh kemajuan ilmu pengetahuan dan teknologi terhadap negara dalam bingkai Bhineka Tunggal Ika.

Merancang dan mengkampanyekan persatuan Mengkaji isu-isu aktual ketahanan nasional terkait dan kesatuan bangsa sebagai upaya menjaga dan dengan persatuan dankesatuan bangsa. mempertahankan Negara Kesatuan Republik Indonesia

Merumuskan alternatif solusi stategi persatuan dan kesatuan bangsa sebagai upaya menjaga dan mempertahankan NKRI.

Sumber : Olahan Peneliti, 2018.

\section{SIMPULAN}

Berdasarkan analisis data dan pembahasan hasil penelitian, dapat ditarik simpulan sebagai berikut.

Pertama, deskripsi isi pendidikan kewarganegaraan berdasarkan isu aktual bidang ketahanan nasional yaitu tentang isu-isu ideologi, politik, ekonomi, sosial budaya, dan pertahanan keamanan (ipoleksosbudhankam) berupakajian pemetaan kompetensi dasaryang diterjemahkan menjadi indikator-indikator untuk mencapai tujuan dari kompetensi dasar pendidikan kewarganegaraan persekolahan. Berdasarkan analisis data, diperlukan kajian isu aktual ketahanan nasional untuk mendukung isi pendidikan kewarganegaraan persekolahan sebagai dasar perumusan indikator-indikator pembelajaran.

Kedua, adapun dalam prosesnya, dilakukan analisis kajian isu aktual ketahanan nasional, kemudian melakukan analisis design atau perancangan kajian isu aktual ketahanan nasional, dilanjutkan pengembangan isi berupa analisis kompetensi dasar dan pemetaan indikator, selanjunya pemetaan kompetensi dasar dan indikator tersebut dapat diimplementasikan dalam proses pembelajaran, dan pada akhirnya dilakukan evaluasi proses pembelajaran.

\section{DAFTAR PUSTAKA}

Adger, W. Neil, 2003, 'Social Capital, Collective Action, and Adaptation to Climate Change', Economic Geography Journal 79, (4).

Alberty, H., 1954, Reorganizing the High School Curriculum, New York: The Appleton Century Crafts.

Barnett, Michael D, 2004, 'Congress must Recognize the Need for Psychological Resilience in an Age of Terrorism', Families Systems \& Health Journal2(2). 
Bermanis, 2007, 'I vs. We: Collective and Individual Factors of Reserve Service Motivation During War and Peace', Armed Forces \& Society 34 (4).

Elran,Meir,2006, Israel's National Resilience: The Influence of the Second Intifada on Israeli Society, Tel Aviv, Israel: Jaffe Center for Strategic Studies, Tel Aviv University.

Friedland,Nehemia, 2006 "Introduction The "Elusive" Concept of Social Resilience," in The Concept of Social Resilience, ed. Asher Arian et al. (Haifa: The Technion. Samuel Neaman Institute,), 7-10.

Kirschenbaum,Alan (2006): 'Terror, Adaptation and Preparedness: A Trilogy for Survival', Journal of Homeland Security and Emergency Management 3 Article 3.

Kosasih, 2014, Strategi Belajar dan Pembelajaran Implementasi Kurikulum 2013, Bandung: Penerbit Yrama Widya.

Kuntarti, R., 2014, 'Implikasi Perubahan Kurikulum Pendidikan Pada Sistem Pendidikan Taruna Terhadap Pencapaian Kualitas Taruna Guna Mendukung Ketahanan Satuan (Studi Di Akademi Militer, Magelang, Jawa Tengah)'. Jurnal Ketahanan Nasional. Vol. 20 No. 1, April 2014, hh. 39-46.

Miles, Matthew B. \& A. Michael Huberman, 1992, "Qualitative Data Analysis", Terjemahan Tjetjep Rohendi Rohidi, Analisis Data Kualitatif, Buku Sumber
Tentang Metode-Metode Baru, Cetakan I, Jakarta: UI Press.

Saputro, 2015, 'Peran Partai Politik Dalam Pendidikan Politik Generasi Muda Dan Implikasinya Terhadap Ketahanan Politik Wilayah (Studi Di Dpd Ii Partai Golongan Karya Kota Malang Jawa Timur Tahun 2009 - 2014)', Jurnal Ketahanan Nasional, Vol. 21, No. 1, April 2015, hh. 34-42.

Shaul Kimhi \& Yohanan Eshel, "Individual and Public Resilience and Coping with Long Term Outcomes of War," Journal of Applied Behavioral Research 14 (2009): 70-89.

Soedarsono, S., 1997, Ketahanan Pribadi Dan Ketahanan Keluarga Sebagai Tumpuan Ketahanan Nasional, Jakarta: Pt Intermasa. Sudjana, N., 2017, Dasar-Dasar Proses Belajar Mengajar, Bandung: Sinar Baru Algensindo

Suwignyo, A Dan Yuliantri, R, D, A., 2018, 'Praktik Kewargaan Sehari-Hari Sebagai Ketahanan Sosial Masyarakat Tahun 1950An (Sebuah Tinjauan Sejarah)', Jurnal Ketahanan Nasional, Vol. 24, No.1, April 2018, hh. 94-116.

Tanner, D., 1975, Curriculum Development Theory into Practice, New York: Mc Millan Publisshing Co Inc.

Wuryan, S., dan Syaifullah, 2008, Ilmu Kewarganegaraan (Civics), Bandung: Laboratorium Pendidikan Kewarganegaraan, UPI Bandung. 